\title{
Styrene and styrene dimer derivatives, cyclohexene, tert-butylbenzene and cumene as test reactions for acid strength measurements of crystalline and amorphous silica-aluminas, sulfated oxides and Amberlyst
}

\author{
M. Marczewski ${ }^{1}$ - H. Marczewska ${ }^{1}$ - D. Popielarska ${ }^{1}$. \\ K. Ciecierska ${ }^{1}$ - M. Herman ${ }^{1}$ - A. Kamińska ${ }^{1}$. \\ E. Kamińska ${ }^{1} \cdot$ R. Wiedro ${ }^{1}$ A. Roguska ${ }^{1}$
}

Received: 8 December 2014/ Accepted: 8 March 2015/Published online: 18 March 2015

(C) The Author(s) 2015. This article is published with open access at Springerlink.com

\begin{abstract}
The minimal $\mathrm{H}_{\mathrm{O}}$ values required for cyclohexene, $\boldsymbol{\alpha}$-methylstyrene, styrene, 2,4-diphenyl-4-methyl-1-pentene, 4-phenyl-1-butene, tert-butylbenzene and cumene to undergo the chosen test reactions over solid acids at $303 \mathrm{~K}$ have been established. The chosen reactions and the respective $\mathrm{H}_{\mathrm{O}}$ min values obtained are as follows: $\alpha$-methylstyrene and styrene oligomerization $(-3.3$ and -5.3$), 2,4-$ diphenyl-4-methyl-1-pentene and 4-phenyl-1-butene oligomerization and isomerization ( -6.9 and -7.9$)$, cyclohexene oligomerization $(-7.8)$, tert-butylbenzene disproportionation $(-10.8)$ and cumene disproportionation $(-11.5)$. The above mentioned test reactions were used to study the acid strength of different solid acids. The results can be presented as follows: (a) $\gamma-\mathrm{Al}_{2} \mathrm{O}_{3}$ was practically inactive in the performed reactions due to the lack of Brønsted acid centers of $\mathrm{H}_{\mathrm{O}} \leq-3.3$; (b) $-\mathrm{SO}_{3} \mathrm{H}$ groups of Amberlyst XN-1010 exhibit acid strength of $-7.9<\mathrm{H}_{\mathrm{O}} \leq-7.8$; (c) amorphous silica-alumina (13 and $45 \% \mathrm{Al}_{2} \mathrm{O}_{3}$ ), $\mathrm{HY}$ and HZSM-5 zeolites possess Brønsted acid sites of acid strength $-10.8<\mathrm{H}_{\mathrm{O}} \leq-7.9$; (d) sulfated oxides: $\mathrm{Al}_{2} \mathrm{O}_{3} /(8 \%) \mathrm{SO}_{4}{ }^{2-}$ and $\mathrm{TiO}_{2} /(8 \%) \mathrm{SO}_{4}{ }^{2-}$ possesses strong protic sites of $-11.5<\mathrm{H}_{\mathrm{O}} \leq-10.8$.
\end{abstract}

Keywords Acidity scale $\cdot$ Solid acids $\cdot$ Test reactions $\cdot$ Sulfated oxides ·

Silicaalumina $\cdot$ Zeolites

M. Marczewski

marekm@ch.pw.edu.pl

1 Chemistry Department, Warsaw University of Technology, Noakowskiego 3,

00-662 Warsaw, Poland 


\section{Introduction}

The acidic properties of solid acids such as silica-aluminas, zeolites, heteropolyacids or sulfated oxides have always been the subject of numerous studies [1-3]. However, their acid strength values, which determine their catalytic activity, are either difficult to find in the literature, or presented as rough estimates. There are difficulties encountered in the measurement of the acid strength of solids because they have been generally performed using various, basing on different foundations techniques. The most important are Hammett indicator adsorption, measurements of heat of adsorption/desorption of probe molecules, NMR measurements of the chemical shift of protons of surface hydroxyls or selected atoms in adsorbed probe molecules and the use of test reactions. None of these methods has a universal character and each one has its constraints.

\section{Direct $\mathrm{H}_{\mathrm{O}}$ measurements. Indicator adsorption}

The indicator adsorption method utilizes bases of known $\mathrm{pK}_{\mathrm{BH}+}$ constant value, which change color on protonation. A visual observation of such change leads to the conclusion that the acid strength of the surface center is $\mathrm{H}_{\mathrm{O}} \leq \mathrm{pK} \mathrm{BH}_{+}$[1]. Spectroscopic methods (NMR [4], IR [5], UV [6, 7] ) are sometimes used to validate proton-indicator interaction. Direct measurements based on the adsorption of Hammett indicators could be misleading because indicator-surface interactions differ from protonation [8, 9] since the equilibrium:

$$
\mathrm{BH}^{+} \leftrightarrows \mathrm{B}+\mathrm{H}^{+}
$$

(B denotes Hammett indicator base), which is the basis of the $\mathrm{H}_{\mathrm{O}}$ scale can be affected by $\mathrm{B}$ and $\mathrm{BH}^{+}$adsorption on Lewis acid sites and basic centers, respectively. Hall et al. [10] proposed taking into consideration another more general equilibrium i.e.

$$
\mathrm{B}+\mathrm{HA} \rightleftharpoons \mathrm{BH}^{+}+\mathrm{A}^{-}
$$

This includes the reaction of indicator with an acid (dissociation equilibrium constant K). Such a modification leads to a new equation for $\mathrm{H}_{\mathrm{O}}$

$$
\mathrm{H}_{\mathrm{O}}=\mathrm{pK}_{\mathrm{BH}+}-\log \frac{(\mathrm{HA})}{\left(\mathrm{A}^{-}\right)}-\log \mathrm{K}
$$

Since the equilibrium constant $\mathrm{K}$ and $(\mathrm{HA}) /\left(\mathrm{A}^{-}\right)$ratio are not known, then $\mathrm{H}_{\mathrm{O}}$ become too complicated to calculate in comparison with the simple formula $\mathrm{H}_{\mathrm{O}}=\mathrm{pK}_{\mathrm{BH}+}[1]$. Then the authors conclude that it is more reliable to compare the acid strength of solids experimentally with that of acid solutions like $\mathrm{H}_{2} \mathrm{SO}_{4}-\mathrm{H}_{2} \mathrm{O}$ or $\mathrm{HSO}_{3} \mathrm{H}-\mathrm{SbF}_{5}$ rather than use the $\mathrm{H}_{\mathrm{O}}$ function values obtained from indicator adsorption experiments. For these reasons, the application of correlation of cumene dealkylation results [11] and energy of Ar desorption [12] with $\mathrm{H}_{\mathrm{O}}$ values based on indicator adsorption measurements should be used with care. 
Katada et al. [13] proposed to treat ammonia as a Hammett indicator and they developed a formula relating $\mathrm{H}_{\mathrm{O}}$ with the heat of ammonia adsorption $\left(\Delta \mathrm{H}^{\mathrm{O}}\right)$ :

$$
\mathrm{H}_{\mathrm{O}}=-1.75 \times 10^{-4} \times \Delta \mathrm{H}^{\mathrm{O}}+15.9
$$

The $\Delta \mathrm{H}_{\mathrm{O}}$ value $\left(160 \mathrm{~kJ} \mathrm{~mol}^{-1}\right)$ obtained experimentally for sulfated zirconia (SZ) indicated on acid strength close to $-12 \mathrm{H}_{\mathrm{O}}$ units. In the subsequent work, Katada et al. [14] improved the TPD profile analysis and showed that single ammonia desorption peak could be deconvoluted into a set of peaks from which some of them were characterized by $\Delta \mathrm{H}_{\mathrm{O}}>160 \mathrm{~kJ} \mathrm{~mol}^{-1}$. This finding allowed the classification of $\mathrm{SZ}$ as a superacid $\left(\mathrm{H}_{\mathrm{O}}<-12\right)$.

\section{Indirect $\mathrm{H}_{\mathrm{O}}$ measurements}

Hall et al. [10] proposed to estimate $\mathrm{H}_{\mathrm{O}}$ value for solid acids using indirect methods. They are based on an observation that in $\mathrm{H}_{2} \mathrm{SO}_{4}-\mathrm{H}_{2} \mathrm{O}$ solutions, the position of UV absorption band of an indicator (4-nitrotoluene, 4-nitrofluorobenzene) depends on the acid strength of the solution. The obtained correlation-band shift/ $\mathrm{H}_{\mathrm{O}}$ allowed the estimation of acid strength of several solid acids like different zeolites and silicaaluminas [10]. Lavalley et al. [15] used the zeolites characterized by Hall as a basis to correlate a shift of IR band of adsorbed $\mathrm{CO}$ with $\mathrm{H}_{\mathrm{O}}$ and then to measure acid strength of other solids. Taft and Levins [16] utilized a similar idea for the acidity measurements. They determined a correlation between the $\delta{ }^{19} \mathrm{FNMR}$ chemical shifts in p-fluoroacetophenone and the acid strengths of different $\mathrm{H}_{2} \mathrm{SO}_{4}-\mathrm{H}_{2} \mathrm{O}$ solutions. Based on this finding, Lavalley et al. [17] measured the acid strengths of HZSM-5 zeolites. A similar method based on ${ }^{13}$ CNMR measurements of mesitil oxide molecule interaction with acids allowed Haw et al. [18] to compare the acid strength of zeolites with that of mineral acids and superacids. The Hall correlation [10] has been also used by Fraenkel et al. [19] to link acid strength of acid catalysts with the results of isobutane isomerization at strictly defined condition. For this reaction, the following formula for acid strength was developed:

$$
\mathrm{H}_{\mathrm{O}}=\frac{\mathrm{E}_{\mathrm{a}}}{2.3 \mathrm{RT}_{1 / 2}}-22.4
$$

Here $E_{a}$ and $T_{1 / 2}$ are the apparent activation energy and temperature at $0.5 \%$ of isobutane conversion. The method was verified with the use of some reported data for acids such as: $\mathrm{H}_{2} \mathrm{SO}_{4}(98.1 \mathrm{wt} \%), \mathrm{FSO}_{3} \mathrm{H}$ or $\mathrm{HF}-\mathrm{SbF}_{5}$ and then applied for a set of zeolites: HM, HZSM-5 and HY as well as SZ. The values of acid strength $\left(\mathrm{H}_{\mathrm{O}}\right)$ of acid solutions were estimated at $-10.5,-15.07$ and -26 , while the results were as follows for solid acids: HM -13.7 , HZSM-5 -10, HY -9 and SZ -18.5 . It seems that the obtained results overestimated the acid strengths of zeolites, which, according to Haw [20], did not exceed $-7.46 \mathrm{H}_{\mathrm{O}}$ units. 


\section{Other methods for acid strength determination}

The measurements presented above allowed to express the acid strength of solids using the $\mathrm{H}_{\mathrm{O}}$ scale. However, there are different methods that permit to rank acids according to less objective scales. For example, the heat effects which accompany the interaction of probe molecules with surface sites have been applied for acid strength approximation. Microcalorimetry [21], TPD [22], adsorption [23] or calorimetric titration [24, 25] have been commonly used. The initial heat of ammonia adsorption at $423 \mathrm{~K}[21,26]$, activation energy of ammonia desorption [16] and differential heat of ammonia adsorption [22] can be applied in the classification of solids, especially zeolites, with respect to their acid strength:

$$
\begin{aligned}
& \text { mazzite }>\mathrm{USY}<\text { mordenite }>\mathrm{HZSM}-5>\mathrm{HY}>\mathrm{HX}>\mathrm{HA}<\text { silicalite }[26] \\
& \mathrm{USHY}>\mathrm{HNaUSY}(83)>\mathrm{HNaY}(91)>\mathrm{HNaY}(80) \sim \mathrm{HNaY}(40)>\mathrm{NaY}[22]
\end{aligned}
$$

The numbers in parentheses denote zeolite exchange level.

The comparison of acid strength of other solids is difficult since, for example, the heat of ammonia adsorption on $\mathrm{V}_{2} \mathrm{O}_{5}-\mathrm{ZrO}_{2}$ and $\mathrm{V}_{2} \mathrm{O}_{5}-\mathrm{ZrO}_{2} / \mathrm{SO}_{4}{ }^{2-}$ were found to be 204 and $210 \mathrm{~kJ} \mathrm{~mol}^{-1}$, respectively [27]. It is therefore evident that carrier sulfonation increased acid strength, but both values are close or higher than that observed for the most acidic zeolite (mazzite 190-200 $\mathrm{kJ} \mathrm{mol}^{-1}$ ) [26]. The values of the heat of adsorption of two very different probe molecules like argon [23] and pyridine [24] have also been used as a measure of acid strength:

$$
\begin{gathered}
\mathrm{ZrO}_{2} / \mathrm{SO}_{4}<\text { mordenite }<\mathrm{HZSM}-5<\mathrm{HY}<\text { silicaalumina (argon) } \\
\text { HZSM-5 }<\mathrm{ZrO}_{2} / \mathrm{SO}_{4}<\mathrm{HY} \text { (pyridine) }
\end{gathered}
$$

These results also do not provide a unanimous answer regarding the acid strength especially for SZ and zeolites.

Recently, NMR measurements of the chemical shifts of protons of surface hydroxyls [28] or selected atoms in adsorbed probe molecules such as $\alpha, \beta$ unsaturated ketones [29], acetonitrile [30] or trimethylphosphine oxide [31] have been considered to be the most reliable method. The adsorption of acetone gave numerous results of acid strength of solids. The basis of these measurements is the correlation of $\delta{ }^{13} \mathrm{C}$ chemical shifts with calculated deprotonation energy of acid sites [32]. Some results are presented below [20, 32, 33]:

$$
\begin{aligned}
& \mathrm{FSO}_{3} \mathrm{H}(249)>\mathrm{H}_{3} \mathrm{PW}_{12} \mathrm{O}_{40}(246)>\mathrm{H}_{2} \mathrm{SO}_{4} \\
& \quad 100 \%(245)>\mathrm{USY}(234)>\mathrm{ZrO}_{2} / \mathrm{SO}_{4}^{2-}(227)>\mathrm{TiO}_{2} / \mathrm{SO}_{4}^{2-}(226) \\
& >\mathrm{HZSM}-5(223)>\operatorname{mordenite}(222)>\mathrm{HY}(220)
\end{aligned}
$$

The numbers in parentheses denote the chemical shift ${ }^{13} \mathrm{C}$ atom in acetone molecule. 
According to the presented data only $\mathrm{H}_{3} \mathrm{PW}_{12} \mathrm{O}_{40}$ can be considered as a unique solid superacid. The sulfated oxides and zeolites should be classified merely as strong acids. A comparison of the values of respective chemical shifts $(\delta)$ with those determined for acid solutions should allow for an evaluation of the acid strength of solid acids though this procedure is not entirely conclusive. For example, Farcasiu et al. [9] reported, in the case of acetone applied as probe molecule, that the acid strength of HZSM-5 was in the proximity of that of $70 \% \mathrm{H}_{2} \mathrm{SO}_{4}\left(\mathrm{H}_{\mathrm{O}}=-5.8\right)$ and higher than the values for HY and HX zeolites as well as SZ. Moreover, the observed ${ }^{13} \mathrm{C}$ chemical shift value for adsorbed acetone is a mean of the values of adsorption on several acid sites of varying acid strengths. On the other hand, the application of trimethylphosphine oxide as a more selective probe molecule enables the observation of chemical shifts occurring as a result of its adsorption on particular sites of different acid strength. These results revealed that $5 \%$ of the population of HZSM-5 acid centers are of superacidic character [31].

The use of triethylphosphine oxide as a probe molecule allows to express the acid strengths of solids not only as a chemical shift of ${ }^{31}$ PNMR band but also in Gutmann Acceptor Numbers (AN) scale [34]. This method has been used to compare acid strength of silica, alumina and silica-aluminas with different acid solutions [35].

The application of different methods such as TPD [36], ammonia adsorption measurements [37] as well as the use of isobutane as a test reactant [19] to one solid acid i.e. $\mathrm{ZrO}_{2} / \mathrm{SO}_{4}{ }^{2-}$ allow to state that the acid strength is in the range of $-19<\mathrm{H}_{\mathrm{O}}<-18$ while the results obtained using NMR technique [38, 39], indicate that the acid strength was considerably lower than that of sulfuric acid $\left(\mathrm{H}_{\mathrm{O}}=-12\right)$. Such discrepancies emphasize the need for a simple, accurate and synonymous method for estimation of the acid strength of solids.

\section{Test reaction method of acid strength measurements}

We hereby propose a method for the determination of the acid strength of catalysts $\left(\mathrm{H}_{\mathrm{O}}\right)$ by the application of specific chemical reactions. The catalytic activity of an acid solution can be presented as follows:

$$
\mathrm{S}+\mathrm{H}^{+} \leftrightarrows \mathrm{SH}^{+} \rightarrow \mathrm{P}
$$

Here $\mathrm{S}$ and $\mathrm{P}$ stand for the substrate and the product, respectively.

Bunnett and Olsen [39] proposed that for such a reaction, the rate constant (k) depends on catalyst acid strength $\left(\mathrm{H}_{\mathrm{O}}\right)$ :

$$
\log \mathrm{k}=-\mathrm{n}\left(\mathrm{H}_{\mathrm{O}}+\log \left[\mathrm{H}^{+}\right]\right)+\log \mathrm{k}^{\mathrm{o}}
$$

Here $\mathrm{k}^{\mathrm{o}}$ is the value of the rate constant $\mathrm{k}$ extrapolated to diluted solutions, for which the expression: $\mathrm{H}_{\mathrm{O}}+\log \left[\mathrm{H}^{+}\right]$is equal to zero.

By using the equation above to solve the first order rate equation for a batch reactor system, the conversion $(x)$ can be expressed as a function of $\mathrm{H}_{\mathrm{O}}$ in the formula: 


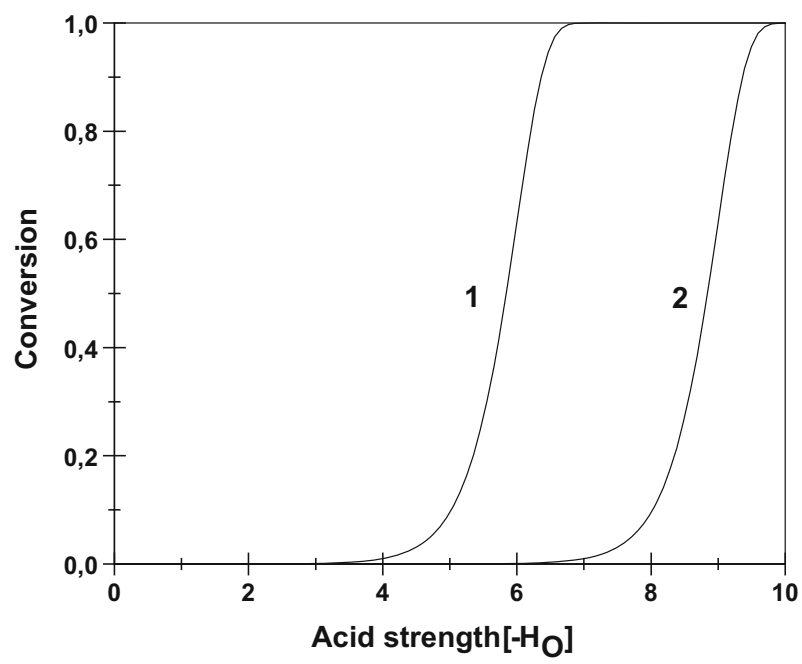

Fig. 1 Dependence of test reactions conversion on catalyst acid strength. Reactants of high (1) and low (2) proton affinity

$$
\mathrm{X}=1-\mathrm{e}^{-\mathrm{A} \times 10^{-\mathrm{Ho}} \tau}
$$

Here $\mathrm{A}$ and $\tau$ are a constant derived from substrate proton affinity and the reaction time, respectively.

It can be seen (Fig. 1) that the reaction proceeds at catalyst sites of varying acid strength depending on proton affinity (basicity) of the substrate. Thus, adequate reaction substrates of specific proton affinity could serve as acid strength indicators.

A similar idea was presented by Deng et al. [32]. They studied a correlation between protonation reaction of different alkenes such as propene, isobutene, styrene and $\alpha$-methylstyrene and the acid strengths of the zeolites. The performed model calculations indicated that depending on the zeolite deprotonation energy (an acid strength measure) the alkenes can be transferred into cations according to their proton affinities. It was concluded that the stronger the basicity of the hydrocarbon, the weaker the acidity of the acid site is required to form stable carbenium ion, which can be considered as true reaction intermediates. This means that if the observed conversion in the test reaction exceeds an arbitrary level indicating that the reaction actually takes place, it can be concluded that the catalyst possesses active centers of acid strength equal or higher of that which is necessary for the reaction to proceed.

There is little information in the literature on the application of such test reactions. Venkatesh et al. [40] used diphenylmethane transformation as test reaction. It was initially observed that the reaction proceeded only if the catalyst acid strength exceeded $\mathrm{H}_{\mathrm{O}}<-12$, so this was further applied to study the acid strength of sulfated $\mathrm{ZrO}_{2}, \mathrm{TiO}_{2}$ and $\mathrm{Fe}_{2} \mathrm{O}_{3}$. All the studied catalysts were able to initiate diphenylmethane transformation and were classified as superacids. In our previous works [41-44], the acid properties of sulfated titania and alumina as well as sodium and chromium doped silica-aluminas and alumina were studied. A 
semiquantitative test reaction method was applied since the minimal acid strength required for the reactions to proceed was not measured, but taken from the literature.

In most works, however, test reactions have been used to classify acid centers only as strong, medium or a weak. Guisnet [45] proposed to use the following reactions for acid strength characterization from weak to strong: 3,3-dimethyl-1butene isomerization $(473 \mathrm{~K}), 2,2$,4-timethylpentane cracking $(623 \mathrm{~K}), 2,4$ dimethylpentane isomerization/cracking $(623 \mathrm{~K})$, 2-methylpentane isomerization/ cracking $(673 \mathrm{~K})$ and hexane isomerization/cracking $(673 \mathrm{~K})$. Such reaction sequence was based on experiments were USHY zeolite with different acid sites poisoned with pyridine was used as a catalyst. Hernandez-Beltran et al. used 4-methylpentane-2-ol transformations at 373-403 K to study the acid properties of sulfated aluminas [46]. The different reaction products obtained indicate the existence of acid sites of varying strength: weak (4-methyl-1-pentene), medium (cis/trans 4-methyl-2-pentene), strong (2-methyl-2-pentene and 2-methyl-1-pentene) and very strong (2,3- and 2,2-dimethylbutenes). The relationship between the acid strength of active centers and the specific reaction products was proposed on the basis of the analysis of reaction mechanism. There are more examples of the application of similar test reactions in the review by Lercher et al. [2].

The aim of this work is to experimentally correlate specific test reactions with the acid strength, expressed in $\mathrm{H}_{\mathrm{O}}$ scale, required for their initiation. For this purpose, a simple experimental procedure that enables the performance of the test reactions in similar conditions both in the presence of acid solutions of known acid strength (calibration step) and over solid catalysts (measurement step) has been developed.

Alkenylaromatics ( $\alpha$-methylstyrene, styrene, 2,4-diphenyl-4-methyl-1-pentene, 4-phenyl-1-butene), alkene (cyclohexene) and alkylaromatics (cumene and tertbutylbenzene) were chosen as reaction substrates. These compounds formed carbenium ions over acids of suitable strength [47-49], which were intermediates of further transformations [1]. The reported reaction conditions (Table 1) indicate that acid solutions of low acid strength $\left(\mathrm{H}_{\mathrm{O}}=-2.2\right)$ at elevated temperature can catalyze only $\alpha$-methylstyrene dimerization. The same reaction for styrene is reported

Table 1 Reaction conditions reported for different acid catalyzed transformation

\begin{tabular}{|c|c|c|c|}
\hline Substrate & $-\mathrm{H}_{\mathrm{O}}$ & Temperature $(\mathrm{K})$ & Ref. \\
\hline \multicolumn{4}{|l|}{ Alkene dimerization } \\
\hline 1-Pentene & 4.9 & 298 & [47] \\
\hline 3-Methyl-1-butene & 9.98 & 273 & [48] \\
\hline \multicolumn{4}{|c|}{ Alkenylaromatics dimerization } \\
\hline$\alpha$-Methylstyrene & 2.2 & reflux & [48] \\
\hline Styrene & 3.5 & reflux & [48] \\
\hline \multicolumn{4}{|c|}{ Cykloalkene skeletal isomerization } \\
\hline Cyclohexene & 15 & 348 & [49] \\
\hline \multicolumn{4}{|c|}{ Alkylaromatics isomerization } \\
\hline Diizopropylbenzene & 15 & 193 & [48] \\
\hline Ditertbutylbenzene & 15 & 193 & [48] \\
\hline
\end{tabular}


when the acid strength of the catalyst increases to $\mathrm{H}_{\mathrm{O}}=-3.5$. The alkenylaromatic compounds having longer than two-carbon side chains can undergo transformation as alkenes. For example, 1-pentene (298 K) and 3-methyl-1-butene (273 K) react in the presence of catalysts with acid strength close to -4.9 and $-9.98 \mathrm{H}_{\mathrm{O}}$ units, respectively. The reactions like alkylaromatics transformation (193 K) were usually performed in the presence of highly acidic media of $\mathrm{H}_{\mathrm{O}}$ close to -15 units. The reported broad range of acid strength of the catalysts used to initiate above reactions is a premise for a choice of such set of the transformation as the test reactions. In order to standardize the method, the reactions were performed in the presence of different acid solutions of known strength at chosen temperature (ambient -303 K). Such procedure allowed to estimate the minimum acid strength required for the reactions to proceed at defined condition (temperature, reactor type, amount of catalyst).

Such a calibrated test reaction method was validated by determining the acid properties of typical solid acids such as Amberlyst, silica-aluminas, zeolites (HY, HZSM-5), pure oxides $\left(\mathrm{Al}_{2} \mathrm{O}_{3}\right)$ whose acid strength has been extensively studied and then used to characterize the solids of still uncertain acid strength like sulfated oxides: $\mathrm{TiO}_{2} / \mathrm{SO}_{4}{ }^{2-}$ and $\mathrm{Al}_{2} \mathrm{O}_{3} / \mathrm{SO}_{4}{ }^{2-}$ (8 wt $\%$ of $\mathrm{H}_{2} \mathrm{SO}_{4}$ ).

\section{Experimental}

\section{Materials}

Solid acids: Amberlyst XN-1010 (Aldrich), silica-aluminas containing 13 and $45 \%$ of $\mathrm{Al}_{2} \mathrm{O}_{3}$ (Ventron GmBH, $\mathrm{S}_{\mathrm{BET}}=392 \mathrm{~m}^{2} \mathrm{~g}^{-1}$ and Pierce Inorganics B.V., $\mathrm{S}_{\mathrm{BET}}=110$ $\mathrm{m}^{2} \mathrm{~g}^{-1}$ ), NaHY (LZ-Y62 Union Carbide, $82 \%$ of exchange, dried $72 \mathrm{~h}$ at $333 \mathrm{~K}$ and then at 373,423 and $523 \mathrm{~K}$ for $24 \mathrm{~h}$ and finally at $773 \mathrm{~K}$ in a stream of dry air) and HZSM-5 (IChP Warsaw, $\mathrm{SiO}_{2} / \mathrm{Al}_{2} \mathrm{O}_{3}=35$, subjected to threefold ionic exchange with $\mathrm{NH}_{4} \mathrm{Cl}$ leading to $\mathrm{H}$-form and then thermal treatment at 333,493 and $823 \mathrm{~K}$ for $24 \mathrm{~h}$ ). The selected oxides for acid strength measurements were: $\mathrm{SiO}_{2}$ (ABCR Karlsruhe, $\mathrm{S}_{\mathrm{BET}}=266 \mathrm{~m}^{2} \mathrm{~g}^{-1}$ ), $\mathrm{TiO}_{2}$ (Degussa P-25, $\mathrm{S}_{\mathrm{BET}}=53 \mathrm{~m}^{2} \mathrm{~g}^{-1}$ ) and $\gamma-\mathrm{Al}_{2} \mathrm{O}_{3}($ Pierce Inorganics, $\mathrm{S}_{\mathrm{BET}}=98 \mathrm{~m}^{2} \mathrm{~g}^{-1}$ ) and sulfated titania and alumina containing $8 \% \mathrm{H}_{2} \mathrm{SO}_{4}$ on alumina and titania [41]. All organic reactants, sulfuric, trifluoromethanesulfuric and trifluoroacetic acids were supplied by Aldrich.

\section{Calibration of the test reaction method}

Test reactions were carried out in the presence of catalysts of estimated acid strength. These were acid solutions whose acid strength had earlier been measured and reported: water-sulfuric acid $[50,51]$ and trifluoroacetic acid-trifluoromethanesulfuric acid (TFA-TFMSA) [52]. This enabled the application of acids of strength in the -5 to $-14.1 \mathrm{H}_{\mathrm{O}}$ unit range. Catalytic activity measurements were carried out under ambient conditions (303 K, Mini Incubator 4010, GLF; shaking: $60 \mathrm{rpm}$, Shaker DOS-20S Elmi Ltd) in a batch reactor using the following procedure. The catalyst was a solid carrier in which an acid solution had been deposited in the pore system while the reactant was a liquid. The carrier, usually $\mathrm{SiO}_{2}(0.125 \mathrm{~g})$ was placed in the 
vial equipped with a screw closure, soaked by the incipient wetness method with an acid of known acid strength $\left(0.25 \mathrm{~cm}^{3}\right)$, then the reactant $\left(1 \mathrm{~cm}^{3}\right)$ was introduced. The organic phase was separated, neutralized after 2 or $24 \mathrm{~h}$ with $5 \% \mathrm{NaHCO}_{3}$ solution and then analyzed. When 3-methylpentane was used as a reactant $\left(0.05 \mathrm{~cm}^{3}\right)$, it immediately vaporized upon injection and gaseous samples were taken for analysis.

In the case of cyclohexene and alkenylaromatics, especially styrene, it was observed that the rate of increase of the concentration of the products was not proportional to the rate of decrease of substrate concentration. The formation of a surface oligomer, which did not desorb under the adopted reaction conditions could be responsible for this phenomenon. In order to estimate correct cyclohexene and alkenylaromatics to oligomer transformation, a known amount of an inert compound-heptane serving as an internal standard was added to it. Total alkenylaromatics conversion (including oligomerization) was calculated according to the following formula:

$$
x_{\text {total }}=1-\frac{\beta_{\text {substr. }}^{\tau}}{\beta_{\text {substr. }}^{\mathrm{o}}}
$$

Here $x_{\text {total }}$ denotes total substrate conversion; $\beta_{\text {substr. }}^{\mathrm{o}}=\frac{S_{\text {substr. }}^{\mathrm{O}}}{S_{\text {stand. }}^{\mathrm{O}}}, \beta_{\text {substr. }}^{\tau}=\frac{S_{\text {substr. }}^{\tau}}{S_{\text {stand. }}^{\tau}}$ are ratios of GC peaks areas for substrate and internal standard at beginning of the reaction and at reaction time equal to $\tau$.

\section{Acid strength measurements}

The solid acid like silica-alumina, zeolite, sulfate oxides or alumina ( $0.5 \mathrm{~g})$ was placed in a glass batch reactor $\left(76 \mathrm{~cm}^{3}\right)$ connected to a vacuum/dry air line and activated at $753 \mathrm{~K}$ for $3 \mathrm{~h}$ in a stream of dry air. The reactor was cooled to the required temperature, the catalyst transferred in the stream of dry air into a glass vial $\left(5 \mathrm{~cm}^{3}\right)$ equipped with a screw closure and then the substrates $\left(1 \mathrm{~cm}^{3}\right)$ injected. The reactants formed a liquid phase over a catalyst. In some cases, $30 \mathrm{wt} \%$ heptane solutions of reactants were used as substrates. The products were analyzed after $24 \mathrm{~h}$ of the reaction time (temperature: 303 K, Mini Incubator 4010, GLF; shaking: 60 rpm, Shaker DOS-20S Elmi Ltd). Amberlyst was used as a catalyst without any activation procedure.

The products of alkenes, alkenyl- and alkylaromatics reactions were analyzed in a GC (Agilent $6890 \mathrm{~N}$ with FID detector) equipped with a $30 \mathrm{~m}$ HP5 capillary column (I.D. $0.32 \mathrm{~mm}, \mathrm{~d}_{\mathrm{f}} 0.25 \mu \mathrm{m}$, temperature $343 \mathrm{~K}(5 \mathrm{~min})$, to $543 \mathrm{~K}$ at $3 \mathrm{~K} /$ min). For 3-methylpentane reaction products, a $100 \mathrm{~m} \mathrm{HP1} \mathrm{capillary} \mathrm{column} \mathrm{(I.D.}$ $0.25 \mathrm{~mm}, \mathrm{~d}_{\mathrm{f}} 0.5 \mu \mathrm{m}$, temperature $323 \mathrm{~K}$ ) was used.

\section{Results}

\section{Calibration of the test reaction method}

The test reaction method, in order to be quantitative, has to correlate the acid strength of a catalyst with the ability to activate a particular reactant molecule to 
undergo chemical transformation. This can be achieved in the calibration procedure when a reaction is examined in the presence of a catalyst of known acid strength. For this purpose, acid solutions of $\mathrm{H}_{2} \mathrm{O}-\mathrm{H}_{2} \mathrm{SO}_{4}$ and TFA-TFMSA of acid strength ranging from -5 to $-14.1 \mathrm{H}_{\mathrm{O}}$ units were used. The catalyst was a solid in which an acid solution had been deposited in the pore system according to incipient wetness method. A probable acid solution/carrier interaction was examined in experiments of sulfuric acid of $\mathrm{H}_{\mathrm{O}}=-11.4$ with three oxide supports i.e. $\mathrm{SiO}_{2}, \mathrm{TiO}_{2}$ and $\mathrm{Al}_{2} \mathrm{O}_{3}$. The experiments were performed with 3-methylpentane as a probe reactant because its reactivity is strongly influenced by the concentration of the applied sulfuric acid [53]. The carrier was initially soaked with acid and heated at temperatures from 298 to $480 \mathrm{~K}$ for $2 \mathrm{~h}$ in order to facilitate the acid-carrier reactions leading to surface sulfates and the formation of water. This should lead to a decrease in the acid concentration in the carrier pores and in consequence influence 3-methylpentane conversion. However, the obtained results showed that only the $\mathrm{SiO}_{2} / \mathrm{H}_{2} \mathrm{SO}_{4}$ system can be considered stable (Fig. 2) because 3-methylpentane conversion remained constant at temperatures from 298 to $353 \mathrm{~K}$. This should indicate that no chemical reaction took place between the acid and the oxide. Hence, it can be used as an inert carrier for a catalytically active phase. A different behavior was observed with $\mathrm{Al}_{2} \mathrm{O}_{3}$ and $\mathrm{TiO}_{2}$. They started reacting with sulfuric acid at 298 and $313 \mathrm{~K}$, respectively. Hence, these oxides cannot be considered as acid phase carriers.

The calibration procedure adopted for the chosen test reactions allowed for a correlation between the commencement of the reaction and the acid strength of acid catalyst required for it to initiate. The results obtained at room temperature $(303 \mathrm{~K})$ for two test reactants, which differ substantially in proton affinity (PA) i.e. $\alpha$ methylstyrene and tert-butylbenzene are gathered in Fig. 3. The presented

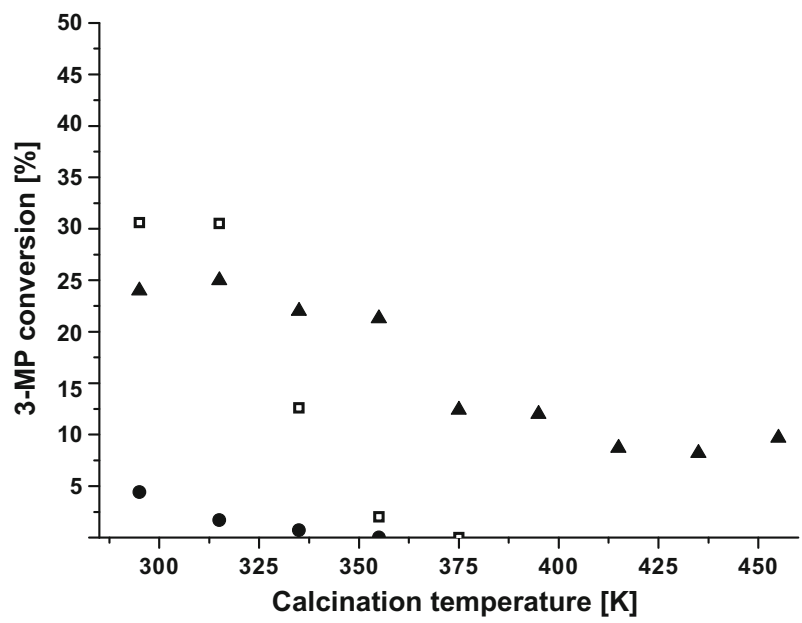

Fig. 2 Influence of calcination temperature on 3-methylpentane conversion for oxides impregnated with $\mathrm{H}_{2} \mathrm{SO}_{4}\left(\mathrm{H}_{\mathrm{O}}=-11.4\right): \mathrm{SO}_{2}$ (filled triangle), $\mathrm{TiO}_{2}$ (square), $\mathrm{Al}_{2} \mathrm{O}_{3}$ (filled circle). Batch reactor, $298 \mathrm{~K}$, catalyst/reactant phase system: solid/gas, reaction time $24 \mathrm{~h}$ 


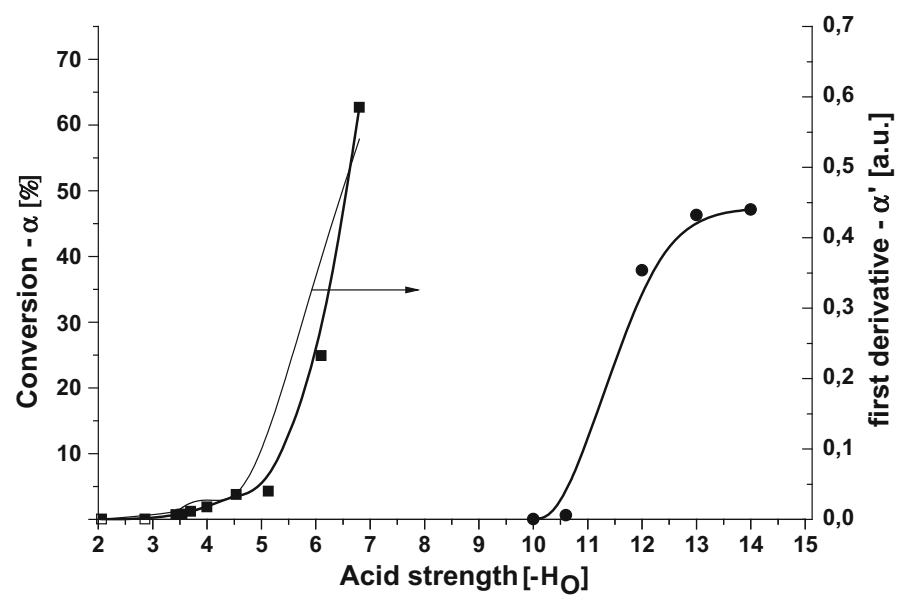

Fig. 3 Dependence of test reactions conversion: $\alpha$-methylstyrene (1) and tert-butylbenzene (2) on catalyst acid strength as well as first derivative of $\alpha$-methylstyrene conversion (3). Batch reactor, $303 \mathrm{~K}$, catalyst/reactant phase system: solid/liquid, reaction time: $24 \mathrm{~h}$. The lines are drawn using nonlinear regression fit of experimental data using $\beta$-spline function

conversions versus acid strength $\left(\mathrm{H}_{\mathrm{O}}\right)$ functions are similar to those discussed previously by Bunnet and Olsen [39] (Fig. 1).

The more basic $\alpha$-methylstyrene (PA equals to $859 \mathrm{~kJ} \mathrm{~mol}^{-1}$ [53]) underwent reaction at a lower catalyst acid strength than tert-butylbenzene (PA equals to $792 \mathrm{~kJ} \mathrm{~mol}^{-1}$ [54]). Therefore, this confirms the relation between catalyst acid strength and conversion in the test reactions.

\section{Validation of chosen test reactions}

The reactions of $\alpha$-methylstyrene, styrene, 2,4-diphenyl-4-methyl-1-pentene in heptane, and 4-phenyl-1-butene were performed with a well-known solid acidAmberlyst XN-1010 at $303 \mathrm{~K}$ in a batch reactor (Fig. 4).

In these experiments, the reactant transformations were followed by long time (up to 7 days i.e. $-168 \mathrm{~h}$ ). $\alpha$-Methylstyrene underwent fast dimerization attaining nearly total conversion after $24 \mathrm{~h}$. Styrene also reacted with dimer formation but after 3 days of reaction obtained products became so viscous that it was very difficult to analyze the sample. If styrene was used as a reactant in heptane solution, the reaction became easy to follow even for high conversion level. It can be better seen if one analyzes the correlation between styrene conversion and acid strength of the catalysts used (Fig. 5).

In the presence of catalysts of acid strength $\mathrm{H}_{\mathrm{O}}>-6.2$, the reaction practically was not observed. But when catalyst acidity exceeded $6.8 \mathrm{H}_{\mathrm{O}}$ units, the reaction begun to proceed giving oligomeric products forming a very viscous gel-like phase. In such a case, it was impossible to find a reliable value for $\mathrm{H}_{\mathrm{O}}$ min. The use of styrene solutions in heptane $(10,30$ and $50 \%)$ allowed to slow down the rate of 


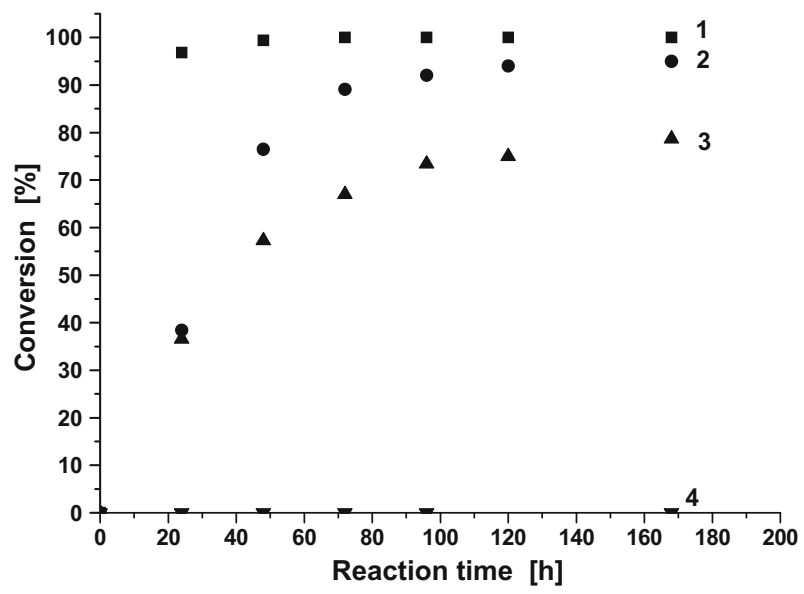

Fig. 4 Dependence of test reaction conversion: $\alpha$-methylstyrene (filled square), styrene (filled circle), 2,4-diphenyl-4-methyl-1-pentene (filled triangle) and 4-phenyl-1-butene (filled inverted triangle) on reaction time. Batch reactor, $303 \mathrm{~K}$, catalyst: Amberlyst XN-1010

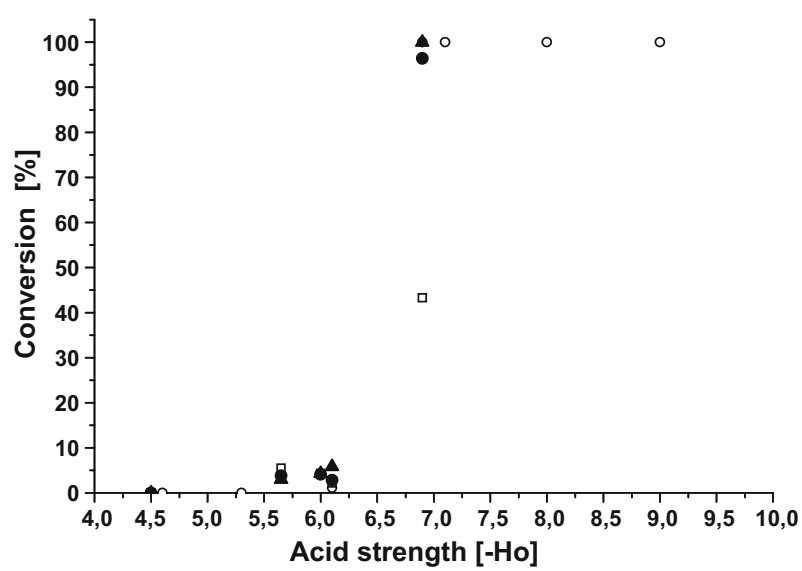

Fig. 5 Dependence of test reactions conversion: styrene (circle), styrene solutions in heptane $10 \mathrm{wt} \%$ (square), $30 \mathrm{wt} \%$ (filled circle) and $50 \%$ (filled triangle) catalyst acid strength. Batch reactor, $303 \mathrm{~K}$, catalyst/reactant phase system: solid/liquid, reaction time: $24 \mathrm{~h}$

oligomerization and then to measure a minimal acid strength required for the reaction initiation.

The $\alpha$-methylstyrene dimer i.e. 2,4-diphenyl-4-methyl- 1-pentene underwent two reactions: double bond migration and dimerization. Only 4-phenyl-1-butene did not reacted even if reaction time reached 7 days. The results indicate that after $24 \mathrm{~h}$, in the presence of suitable catalyst, the results of chosen test reactions were unambiguous. However, in the presence of a catalyst of unknown acid strength, it is possible that one could observe only low reactant conversion. In such a case, it is 
Table 2 Minimal acid strengths $\left(\mathrm{H}_{\mathrm{O}} \mathrm{min}\right)$ necessary for test reaction initiation

\begin{tabular}{llll}
\hline Reactant & Reactions & & \\
\cline { 2 - 4 } & Oligomerization & Carbon chain isomerization & Disproportionation \\
\hline \multirow{2}{*}{ a-Methylstyrene } & $\mathrm{H}_{\mathrm{O}}$ min & & \\
Styrene & -3.3 & & \\
2,4-Phenyl-4-methyl-1-pentene & -6.3 & & \\
Cyclohexene & -6.9 & -6.9 & -10.8 \\
4-Phenyl-1-butene & -7.8 & & -11.5 \\
tert-butylbenzene & -7.9 & -7.9 & \\
Cumene & & & \\
\hline
\end{tabular}

difficult to choose a conversion above which one can deduce that a test reaction begin to proceed. For example, a typical result of the calibration procedure is presented in Fig. 3. Curve 1 depicts a relation between $\alpha$-methylstyrene conversion products (mostly dimers and trimers) and the acid strength $\mathrm{H}_{\mathrm{O}}$ of the catalysts. The presented curve (1) was obtained using nonlinear regression fit of experimental data using $\beta$-spline function. It begins to rise above the abscissa when the acid strength of catalyst is between -2.5 and $-3.5 \mathrm{H}_{\mathrm{O}}$ units. This is easier to see when one analyzes the shape of the first derivative of the conversion $\left(\frac{\partial \alpha}{\partial H_{O}}\right)$ (curve 3). Above $-3.3 \mathrm{H}_{\mathrm{O}}$ units, the first derivative $\alpha^{\prime}$ begins to rise noticeably indicating that the reaction has actually started (conversion level reached about $0.6 \%$ ). A careful examination of presented relations allow to conclude that there is no unique and objective $\mathrm{H}_{\mathrm{O}}$ value, which separate the acid strength region of zero or nearly zero conversion zone from the reaction one. In the case of butane transformation as a test reaction, $0.1 \%$ conversion was reported as a positive result [55], while in the other work [37], a considerably higher conversion $(0.8 \%)$ for the heptane test reaction was interpreted as a lack of transformation. In our work, we arbitrarily assumed that a reaction begins at $\mathrm{H}_{\mathrm{O}}$ min when $\alpha^{\prime}$ become higher than zero and the conversion attains the value of $0.5-1.0 \%$.

\section{$\mathrm{H}_{\mathrm{O}} \min$ measurements}

The values of minimal acid strengths $\left(\mathrm{H}_{\mathrm{O}} \mathrm{min}\right)$ necessary for the initiation of test reactions are presented in Table 2.

They correspond to substrate conversion ranged between 0.5 and 1.0. A similar value $(0.5 \%)$ of isobutane conversion was used by Hall [10] and Fraenkel [19] for acid strength measurements.

$\alpha$-Methylstyrene was the most reactive of all the studied alkenes. It underwent dimerization when the value of the catalyst acid strength attained $\mathrm{H}_{\mathrm{O}}=-3.3$. The remaining alkenylaromatics and cyclohexene began to react at catalyst acidity values higher than: -5.3 (styrene), -6.9 (2,4-diphenyl-4-methyl-1-pentene), -7.8 (cyclohexene) and -7.9 (4-phenyl-1-butene). Oligomerization and double bond 
shift were the main transformations observed. Such reactivity range is in agreement with both factors: the stability of carbenium ion intermediates [1] and the steric hindrances (Graph 1).

Proton addition to the aromatic ring requires a higher acid strength than in the case of alkenes so their reactions proceeded in the presence of very strong acids of $-11.5 \leq \mathrm{H}_{\mathrm{O}} \leq-10.8$ at room temperature.

The observed reactivity sequence of:

$$
\text { tert-butylbenzene }(792)>\text { cumene (789) }
$$

is in agreement with the stability of migrating alkyl carbenium ions [11] as well as the values of respective proton affinities (numbers in parentheses expressed in $\mathrm{kJ} \mathrm{mol}^{-1}$ ) [54].

\section{Acid strength measurements}

After calibration, the test reaction method was applied to study the acid strength of solid catalysts of known acid-base properties: Brønsted acids like amorphous silicaaluminas (13 and $45 \%$ of $\mathrm{Al}_{2} \mathrm{O}_{3}$ ), zeolites HZSM-5 $(\mathrm{Si} / \mathrm{Al}=35)$ and $\mathrm{HY}$, as well as a high surface area sulfate resin i.e. Amberlyst XN-1010; a very weak Brønsted acid and a strong Lewis acid such as $\gamma-\mathrm{Al}_{2} \mathrm{O}_{3}$ and then two sulfated oxides whose acidity is still a matter of controversy: $\mathrm{TiO}_{2} / \mathrm{SO}_{4}{ }^{2-}$ and $\mathrm{Al}_{2} \mathrm{O}_{3} / \mathrm{SO}_{4}{ }^{2-}$ with $\mathrm{H}_{2} \mathrm{SO}_{4}$ content equal to $8 \%$. The obtained results (Table 3 ) led to the following conclusions:

- A strong Lewis acid such as $\gamma-\mathrm{Al}_{2} \mathrm{O}_{3}$ did not catalyze any of the applied test reaction. It therefore does not possess Brønsted acid centers of $\mathrm{H}_{\mathrm{O}} \leq-3.3$.

- The Amberlyst initiated the transformation of $\alpha$-methylstyrene, styrene and 2,4diphenyl-4-methyl-1-pentene. 4-Phenyl-1-butene was not converted into any products. Thus the Amberlyst possesses acid strength of $-7.9<\mathrm{H}_{\mathrm{O}} \leq-6.9$.

- Typical solid acids like amorphous silica-aluminas and zeolites (HY, HZSM-5) catalyzed the reactions of $\alpha$-methylstyrene, styrene, 2,4-diphenyl-4-methyl-1pentene and 4-phenyl-1-butene. tert-Butylbenzene was not able to react in their presence. This indicated that the catalysts possessed Brønsted centers of acid strength $-10.8<\mathrm{H}_{\mathrm{O}} \leq-7.9$. The low conversion observed for the one of the most basic reagent i.e. styrene for the zeolites may be caused by the blocking of the micropore structure by styrene oligomers-coke precursors.

The above conclusions confirm that the test reaction method allows an approximate evaluation of the catalyst acid strength and can be used to study the acid properties of sulfated oxides. The latter catalyzed the reactions of all alkenylaromatic substrates as well as that of tert-butylbenzene. This indicates that disproportionation reactions catalyzed by Brønsted acid centers have most probably taken place. $\mathrm{Al}_{2} \mathrm{O}_{3} / \mathrm{SO}_{4}{ }^{2-}$ and $\mathrm{TiO}_{2} / \mathrm{SO}_{4}{ }^{2-}$ can therefore be said to possess Brønsted acid centers of acid strength $\mathrm{H}_{\mathrm{O}} \leq-10.8$. On the other hand, the lack of cumene transformation products limits the acid strength of these solids to $\mathrm{H}_{\mathrm{O}}>-11.5$. 
Table 3 Acid strength measurements

\begin{tabular}{|c|c|c|c|c|c|c|c|}
\hline \multirow{2}{*}{$\begin{array}{l}\text { Catalyst/conditions }{ }^{\mathrm{a}} \\
\mathrm{H}_{\mathrm{O}}\end{array}$} & \multicolumn{7}{|c|}{ Test reaction results ${ }^{\mathrm{b}}(\%)$} \\
\hline & $\begin{array}{l}-3.3 \\
\alpha-M S\end{array}$ & $\begin{array}{l}-5.3 \\
\text { St }\end{array}$ & $\begin{array}{l}-6.9 \\
\text { dPh-4-M-1-P }\end{array}$ & $\begin{array}{l}-7.8 \\
\text { CHXen }\end{array}$ & $\begin{array}{l}-7.9 \\
\text { Ph-1-B }\end{array}$ & $\begin{array}{l}-10.8 \\
\mathrm{t}-\mathrm{BB}\end{array}$ & $\begin{array}{l}-11.5 \\
\text { Cum }\end{array}$ \\
\hline \multicolumn{8}{|l|}{$\gamma-\mathrm{Al}_{2} \mathrm{O}_{3}$} \\
\hline $\mathrm{a}$ & 0.0 & 0.0 & 0.0 & 0.0 & 0.0 & 0.0 & 0.0 \\
\hline \multicolumn{8}{|l|}{ Amberlyst } \\
\hline a & 96.8 & 38.4 & 36.6 & & & 0.0 & 0.0 \\
\hline $\mathrm{b}$ & & & & 32.1 & & & \\
\hline $\mathrm{c}$ & & & & & 0.0 & & \\
\hline \multicolumn{8}{|l|}{$\mathrm{SiO}_{2}-\mathrm{Al}_{2} \mathrm{O}_{3}(45 \%)$} \\
\hline a & 81.2 & 71.0 & 80.5 & & & 0.0 & 0.0 \\
\hline $\mathrm{b}$ & & & & 14.7 & & & \\
\hline $\mathrm{c}$ & & & & & 92.5 & & \\
\hline \multicolumn{8}{|l|}{$\mathrm{SiO}_{2}-\mathrm{Al}_{2} \mathrm{O}_{3}(13 \%)$} \\
\hline a & 100.0 & 95.0 & 81.2 & & & 0.0 & 0.0 \\
\hline $\mathrm{b}$ & & & & 56.5 & & & \\
\hline $\mathrm{c}$ & & & & & 100.0 & & \\
\hline \multicolumn{8}{|l|}{ HZSM-5 } \\
\hline \multicolumn{8}{|l|}{$\mathrm{a}$} \\
\hline $\mathrm{b}$ & 67.4 & 0.0 & 16.6 & 5.5 & & 0.0 & 0.0 \\
\hline c & & & & & 47.8 & & \\
\hline \multicolumn{8}{|l|}{ HY } \\
\hline \multicolumn{8}{|l|}{$\mathrm{a}$} \\
\hline $\mathrm{b}$ & 97.0 & 14.3 & 96.1 & 34.1 & & 0.0 & 0.0 \\
\hline c & & & & & 36.3 & & \\
\hline \multicolumn{8}{|l|}{$\mathrm{Al}_{2} \mathrm{O}_{3} / \mathrm{SO}_{4}{ }^{2-}(8 \%)$} \\
\hline a & & & & & & 1.3 & 0.0 \\
\hline $\mathrm{b}$ & 100.0 & 100.0 & 100.0 & 66.1 & & & \\
\hline c & & & & & 100.0 & & \\
\hline \multicolumn{8}{|l|}{$\mathrm{TiO}_{2} / \mathrm{SO}_{4}{ }^{2-}(8 \%)$} \\
\hline a & & & & & & 17.3 & 0.0 \\
\hline $\mathrm{b}$ & 100.0 & 100.0 & 91.5 & 45.6 & & & \\
\hline $\mathrm{c}$ & & & & & 100.0 & & \\
\hline
\end{tabular}

${ }^{\mathrm{a}}$ Reaction conditions: $303 \mathrm{~K}$, a-catalyst $0.5 \mathrm{~g}$, reactant $2 \mathrm{ml}$; b-catalyst $0.5 \mathrm{~g}$, reactant $(30 \%$ in heptane) $2 \mathrm{ml}$; c-catalyst $0.5 \mathrm{~g}$, reactant (10\% in heptane) $2 \mathrm{ml}$

${ }^{\mathrm{b}}$ Conversion after $24 \mathrm{~h}$ into products of Brønsted acid catalyzed reactions; $\alpha$-MS, St, 4-dP-2-M-1-Pe, $\mathrm{CHXen}, \mathrm{Ph}-1-\mathrm{B}, \mathrm{t}-\mathrm{BB}$ and Cum mean: $\alpha$-methylstyrene, styrene, 2,4-diphenyl-4-methyl-1-pentene, cyclohexene, 4-phenyl-1-butene, tert-butylbenzene and cumene 


\section{Discussion}

Many attempts have been made to express acid strength of solids in terms of $\mathrm{H}_{\mathrm{O}}$. Different approaches were presented in the Introduction section: the direct measurements using adsorption of Hammett indicators, methods based on test reactions (kinetics of isobutane transformation, diphenylmethane reaction), NMR measurements or $\mathrm{NH}_{3}$ thermodesorption. The application of these methods to compare the acid strength of sulfated oxides with that of typical solid acids such as zeolites does not give coherent results. These catalysts are sometimes classified as superacids and sometimes as solids of lower acid strength than $100 \% \mathrm{H}_{2} \mathrm{SO}_{4}$ $\left(\mathrm{H}_{\mathrm{O}}=-12\right)$. Our proposition of acid strength measurements is close to indicator method where instead of color change observation the chemical transformation of protonated molecules is measured.

The method based on the results of several test reactions performed in the presence of acid solutions of strictly defined acid strength $\left(\mathrm{H}_{\mathrm{O}}\right)$. In the presence of acid catalysts, alkenyl- and alkylaromatics undergo numerous transformations i.e. isomerization, oligomerization and disproportionation reactions. All reactions begin with the protonation of the reacting molecule. This reaction step can take place only if the acid strength of the catalyst is high enough to assure proton transfer from a catalyst to the reactant.

The obtained results (Figs. 3 and 4) prove that it is possible to find the minimal acid strength of a catalyst $\left(\mathrm{H}_{\mathrm{O}} \mathrm{min}\right)$ at which a particular test reaction begins to proceed at given conditions (batch reactor, temperature and reaction time). A prolonged reaction time $(24 \mathrm{~h})$ assured that even if a reaction rate is diffusion controlled the reaction products can be observed.

It is interesting to compare the obtained values of $\mathrm{H}_{\mathrm{O}}$ min with those presented in the Table 1. The latter give acid strength values of the catalyst solutions at which the reactions were performed at laboratory scale in order to synthesize the specific products. For example, the $\alpha$-methylstyrene dimer can be prepared in the presence of sulfuric acid of $\mathrm{H}_{\mathrm{O}}=-2.2$ at reflux temperature while at ambient temperature the reaction needs the catalyst of higher acid strength namely $\mathrm{H}_{\mathrm{O}}$ min $=-3.3$. Double bond activation in alkenes (isomerization) was reported to occur in the presence of the catalysts of $-9.98<\mathrm{H}_{\mathrm{O}}<-4.9$ at close to ambient temperatures, while our results reveal that the minimal acid strength needed for alkenylaromatics double-bond isomerization should be equal to -6.9 and $-7.8 \mathrm{H}_{\mathrm{O}}$ units (isomerization of 2,4-diphenyl-4-methyl-1-pentene and 4-phenyl-1-butene). tert-Butylbenzene aromatic ring protonation (di-tert-butylbenzene isomerization) was performed in the presence of $\mathrm{BF}_{3}-\mathrm{HF}$ catalyst at 348 and $193 \mathrm{~K}$. The acid strength of this system is reported to be close to $-15 \mathrm{H}_{\mathrm{O}}$ units at ambient temperature. We were able to precise $\mathrm{H}_{\mathrm{O}}$ min values for tert-butylbenzene reactions as -10.8 . The results discussed above indicate that obtained values of $\mathrm{H}_{\mathrm{O}}$ min for the test reactions are coherent with the reported data.

These findings allowed to propose an acidity scale which links the test reaction results of $\alpha$-methylstyrene, styrene, 2,4-diphenyl-4-methyl-1-pentene, 4-phenyl-1- 


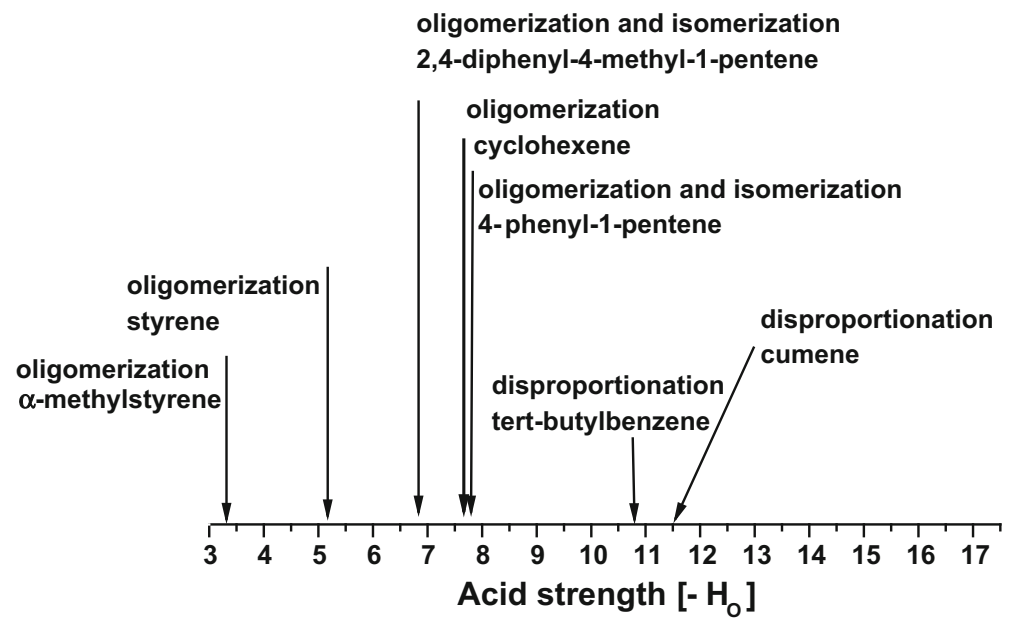

Scheme 1 Test reaction method. Acid strength scale

butene, cyclohexene, cumene, sec-butylbenzene and tert-butylbenzene transformations to respective values of acid strength expressed in $\mathrm{H}_{\mathrm{O}}$ units (Scheme 1).

It is necessary to point out that the results of the test reactions can be treated as a color change resulting of Hammett indicators adsorption. The experimental fact that the test reaction characterized by $\mathrm{H}_{\mathrm{O}}$ min proceeds (conversion exceeding $\sim 0.5-1.0 \%$ after $24 \mathrm{~h}$, reaction products originating from protonated reactant molecule) in the presence of any catalyst studied suggests that apparent catalyst acid strength $\mathrm{H}_{\mathrm{O}}$ is equal or higher than $\mathrm{H}_{\mathrm{O}}$ min.

The main advantage of the application of the test reaction method is the possibility to express acid strength of different solids in the same units as acid solutions. On the other hand, there are some disadvantages. When the conversion of a test reactant is low (close to $1.0 \%$ ), it is necessary to extend the reaction time beyond $24 \mathrm{~h}$ to make sure if a catalytic reaction actually took place. It can be illustrated for tert-butylbenzene transformation initiated by two catalytic systems i.e. possessing acid strength $\mathrm{H}_{\mathrm{O}}$ equal to -14 and -10.8 (Fig. 6). The catalysts were prepared using TFMSA and TFMSA-TFA acids as active phases. The results indicate that if acid strength of the catalyst is considerably higher than $\mathrm{H}_{\mathrm{O}}$ min $(-14$ for example), the reaction proceeds giving disproportionation products with high conversion.

On the other hand, if the acid strength is close to $\mathrm{H}_{\mathrm{O}} \min$, the conversion is low but it rises continuously with the reaction time. Though if acid strength is lower than $\mathrm{H}_{\mathrm{O}}$ min, a test reaction cannot be initiated regardless of reaction time. The last case is illustrated with the results of cumene reaction over $\mathrm{TiO}_{2} / \mathrm{SO}_{4}{ }^{2-}$ catalyst (Fig. 5). The lack of acid catalyzed reaction products even after $47 \mathrm{~h}$ indicate that acid strength of this catalyst is indeed lower than $\mathrm{H}_{\mathrm{O}}$ min for cumene.

The proposed method was subsequently applied to study acid properties of wellknown solid acids such as alumina, Amberlyst resin (XN-1010), silica-aluminas 


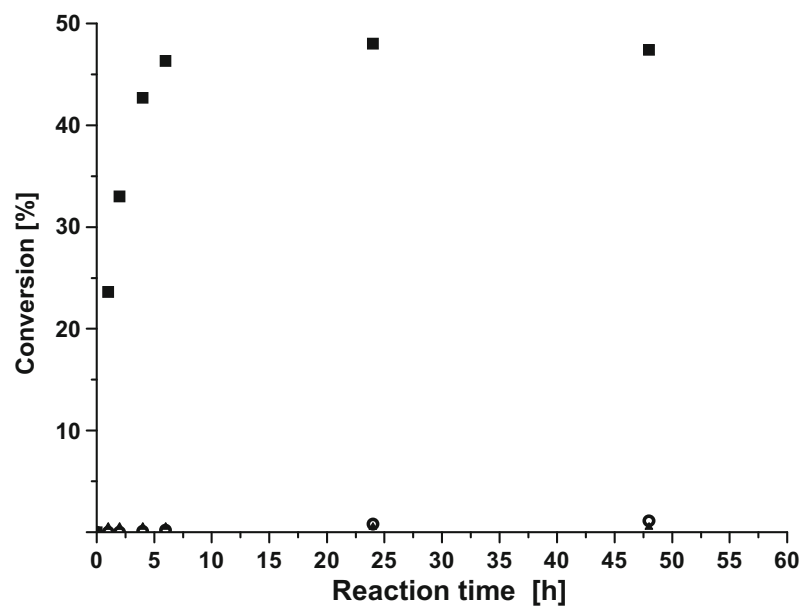

Fig. 6 Dependence of tert-butylbenzene conversion for the catalysts of acid strength equal to $\mathrm{H}_{\mathrm{O}}=-14$ (filled square) and $\mathrm{H}_{\mathrm{O}}=-10.5$ (circle) and for cumene conversion for $\mathrm{TiO}_{2} / \mathrm{SO}_{4}{ }^{2-}$ catalyst (filled triangle) on reaction time. Batch reactor, $303 \mathrm{~K}$, catalyst/reactant phase system: solid/liquid, reaction time: $24 \mathrm{~h}$

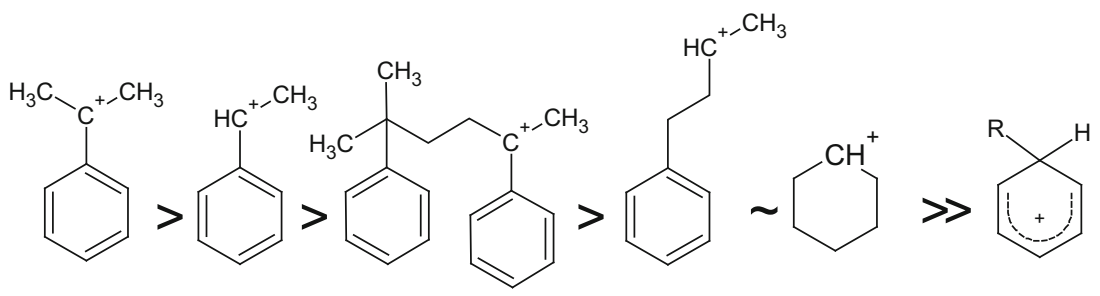

Graph 1 Stability of carbenium ions originating from test reaction substrates

containing 13 and $45 \%$ of $\mathrm{Al}_{2} \mathrm{O}_{3}$ and two zeolites NaHY (LZ-Y62 Union Carbide, $82 \%$ of exchange, HZSM-5 (IChP Warsaw, $\mathrm{SiO}_{2} / \mathrm{Al}_{2} \mathrm{O}_{3}=35$ ). The acid centers of $\mathrm{Al}_{2} \mathrm{O}_{3}$ were too weak to initiate test reactions of all alkenylaromatics. Hence, the acid strength of alumina hydroxyls cannot exceed $\mathrm{H}_{\mathrm{O}}=-3.3$ level. On the other hand, both silica-aluminas as well as $\mathrm{NaHY}$ were able to catalyze all alkenylaromatics used as well as cyclohexene transformations (conversions ranged from 14.3 to $100.0 \%$ ). Only for styrene transformation in the case of HZSM-5 zeolite the conversion was not observed since styrene dimmers formed blocked microporous structure of this catalyst. The other olefin, less reactive, of the close $\mathrm{H}_{\mathrm{O}}$ min value i.e. cyclohexene reacted over HZSM-5 with lower conversions than NaHY with wider pore openings. These results indicate that acid strength of all solid acids studied is higher than -7.9 units on the $\mathrm{H}_{\mathrm{O}}$ scale. The upper limit of the catalyst acid strength is lower than -10.8 since tert-butylbenzene reaction was not observed. Such a value of acid strength is in agreement with published data $\left(-10.44<\mathrm{H}_{\mathrm{O}}<-5.4\right)[8,56]$ and does not confirm the existence of superacid 
Table 4 Acid strength of sulfated alumina and titania

${ }^{\text {a }}$ Indicator adsorption

b Test reactions method

\begin{tabular}{lll}
\hline Catalyst & $\begin{array}{l}\text { Acid strength } \\
\mathrm{H}\end{array}$ & Ref. \\
& $-14.6(923)$ & \\
\hline $\mathrm{Al}_{2} \mathrm{O}_{3} / \mathrm{SO}_{4}{ }^{2-}$ & $-13.8(823)$ & {$[12]^{\mathrm{a}}$} \\
& $-10.8(753)$ & {$[57]^{\mathrm{ab}}$} \\
& $-5.6 \div-3.0(823)$ & This work $^{\mathrm{b}}$ \\
& $-14.6(808)$ & {$[58]^{\mathrm{a}}$} \\
$\mathrm{TiO}_{2} / \mathrm{SO}_{4}{ }^{2-}$ & $-13.41(998)$ & {$[12]^{\mathrm{a}}$} \\
& $-10.8(753)$ & {$[40]^{\mathrm{b}}$} \\
& $-8.2 \div-5.6(773)$ & This work $^{\mathrm{b}}$ \\
& & {$[59]^{\mathrm{a}}$} \\
\hline
\end{tabular}

centers for HZSM-5 zeolite [31]. The consistency of the results obtained with the use of the test reaction method with those already reported allow us to apply the developed method to sulfated oxides. The results indicate that $\mathrm{Al}_{2} \mathrm{O}_{3} / \mathrm{SO}_{4}{ }^{2-}$ is characterized by the presence of strong protic sites. These sites can catalyze not only all alkenylaromatics used as well as cyclohexene transformation (23.1-92.0\%) but also the disproportionation of tert-butylbenzene at $298 \mathrm{~K}(4.5 \%)$. Cumene did not undergo disproportionation/dealkylation reactions under the applied conditions. Thus, the acid strength of sulfated alumina with $\mathrm{H}_{2} \mathrm{SO}_{4}$ content equal to $8 \%$ attains the level of $-11.5<\mathrm{H}_{\mathrm{O}} \leq-10.8$. The Brønsted sites of $\mathrm{TiO}_{2} / \mathrm{SO}_{4}{ }^{2-}$ catalyze acid initiated $\alpha$-methylstyrene $\left(\mathrm{H}_{\mathrm{O}} \min =-3.3\right)$, styrene and cyclohexene $\left(\mathrm{H}_{\mathrm{O}} \mathrm{min}=\right.$ -5.4) and 2,4-diphenyl-4-methyl-1-pentene $\left(\mathrm{H}_{\mathrm{O}} \mathrm{min}=-6.9\right)$ transformations (conversions ranged from $66.7 \%$ to $99.4 \%$ ) and tert-butylbenzene disproportionation (conversion equal to $13.7 \%$ ). Hence, they exhibit a strength of $-11.5<\mathrm{H}_{\mathrm{O}} \leq-10.8$.

The results of acid strength measurements for sulfated oxides studied are gathered in the Table 4.

They do not provide a clear and synonymous answer on acidity of these catalysts. Indicator adsorption measurements result in $\mathrm{H}_{\mathrm{O}}$ values from $\mathrm{H}_{\mathrm{O}} \geq-14.4$ to $-5.6<\mathrm{H}_{\mathrm{O}} \leq-3.0$ for $\mathrm{Al}_{2} \mathrm{O}_{3} / \mathrm{SO}_{4}{ }^{2-}$ and from $\mathrm{H}_{\mathrm{O}} \geq-14.6$ to $-8.2 \mathrm{H}_{\mathrm{O}} \leq-5.6$ for $\mathrm{TiO}_{2} / \mathrm{SO}_{4}{ }^{2-}$. Moreover a reaction test allowed to assign acid strength $\mathrm{H}_{\mathrm{O}} \leq$ -13.4 to sulfated titania.

On the basis of our results, both sulfated oxides cannot be classified as superacids though they catalyze pentane isomerization at ambient temperature [41]. However, they possess strong protic sites $\left(-11.5<\mathrm{H}_{\mathrm{O}} \leq-10.8\right)$. $\mathrm{SO}_{3} \mathrm{H}$ groups bonded to polystyrene chain (Amberlyst) were less acidic than that existing on sulfated oxides surfaces. Their acid strength ranged between -7.9 and $-7.8 \mathrm{H}_{\mathrm{O}}$ units.

\section{Conclusions}

The studies confirm that the test reaction method is a reliable and effective way to measure the acid strength of solids. The minimal acid strength $\left(\mathrm{H}_{\mathrm{O}} \mathrm{min}\right)$ required for a particular test reaction to take place (in brackets) at $296 \mathrm{~K}$ is as follows: 
$\alpha$-methylstyrene and styrene oligomerization (-3.3 and -5.3), 2,4-diphenyl-4methyl-1-pentene and 4-phenyl-1-butene oligomerization and isomerization (-6.9 and -7.9), cyclohexene oligomerization (-7.8), tert-butylbenzene disproportionation $(-10.8)$ and cumene disproportionation $(-11.5)$. The application of the above test reaction allow the measurement of acid strength of the solid acids. (a) $\gamma$ $\mathrm{Al}_{2} \mathrm{O}_{3}$ was practically inactive in the performed reactions due to the lack of Brønsted acid centers of $\mathrm{H}_{\mathrm{O}} \leq-3.3$; (b) $-\mathrm{SO}_{3} \mathrm{H}$ groups of Amberlyst XN-1010 exhibit acid strength of $-7.9<\mathrm{H}_{\mathrm{O}} \leq-7.8$; (c) amorphous silica-alumina (13 and $45 \% \mathrm{Al}_{2} \mathrm{O}_{3}$ ), $\mathrm{HY}$ and HZSM-5 zeolites possess Brønsted acid sites of acid strength $-10.8<\mathrm{H}_{\mathrm{O}} \leq-7.9$; (d) $\mathrm{Al}_{2} \mathrm{O}_{3} /(8 \%) \mathrm{SO}_{4}{ }^{2-}$ and $\mathrm{TiO}_{2} /(4 \%) \mathrm{SO}_{4}{ }^{2-}$ possesses strong protic sites of $-11.5<\mathrm{H}_{\mathrm{O}} \leq-10.8$.

In view of these results, sulfated alumina and titania cannot be considered as superacids.

Acknowledgments This work was partially sponsored by Polish Ministry of Education (project no. 3T0B 074 29) and Faculty of Chemistry, Warsaw University of Technology.

Open Access This article is distributed under the terms of the Creative Commons Attribution License which permits any use, distribution, and reproduction in any medium, provided the original author(s) and the source are credited.

\section{References}

1. Marcilly C (2006) Acido-basic catalysis. Application to refining and petrochemistry. Editions Technip, Paris

2. Lercher JA, Jentys A, Brait A (2008) In: Karge HG, Weitkamp J (eds) Acidity and basicity, molecular sieves, vol 6. Springer, Berlin, pp 153-212

3. Derouane EG, Vedrine JC, Pinto RR, Borges PM, Costa L, Lemos MANDA, Lemos F, Ribeiro FR (2013) Catal Rev Sci Eng 55:454-515

4. Nicholas JB, Haw JF, Beck LW, Krawietz TR, Ferguson DB (1995) J Am Chem Soc 117:12350-12351

5. Ahmed I, Anderson JA, Rochester CH, Dines TJ (1998) J Mol Catal A 135:63-73

6. Chen FR, Courdurier G, Joly JF, Vedrine JC (1993) J Catal 143:616-622

7. Umansky BS, Hall WK (1990) J Catal 124:97-108

8. Fărcaşiu D, Ghenciu A, Li JQ (1996) J Catal 158:116-127

9. Fărcaşiu D, Ghenciu A, Marino G, Rose KD (1997) J Am Chem Soc 119:11826-11831

10. Umansky B, Engelhardt J, Hall WK (1991) J Catal 127:128-140

11. Brei VV (2003) Theor Exp Chem 39:70-73

12. Arata K, Matsuhashi H, Hino M, Nakamura H (2003) Catal Today 81:17-30

13. Katada N, Endo J, Notsu K, Yasunobu N, Naito N, Niwa M (2000) J Phys Chem B 104:10321-10328

14. Katada N, Tsubaki T, Niwa M (2008) Appl Catal A 340:76-86

15. Lavalley JC, Jolly-Feaugas S, Janin A, Saussey J (1997) J Mikrochim Acta [Suppl.] 14: 51-56

16. Taft W, Levins PL (1962) Anal Chem 34:436-437

17. Siman A, Delmotte L, Chezau JM, Janin A, Lavalley JC (1999) Phys Chem Chem Phys 1:1659-1664

18. Xu T, Munson EJ, Haw JF (1994) J Am Chem Soc 116:1962-1972

19. Fraenkel D, Jentzsch NR, Starr CA, Nikrad PV (2010) J Catal 274:29-51

20. Haw JH, Nicholas JB, Xu T, Beck LW, Ferguson DB (1996) Acc Chem Res 29:259-267

21. Spiewak BE, Handy BE, Sharma SB, Dumestic JA (1994) Catal Lett 23:207-213

22. Costa C, Lopes JM, Lemos F, Ribeiro FR (1999) J Mol Catal A 144:221-231

23. Matsuhashi H, Futamura A (2006) Catal Today 111:338-342 
24. Drago RS, Dias JA, Maier TO (1997) J Am Chem Soc 119:7702-7710

25. Drago RS, Kob N (1997) J Phys Chem B 101:3360-3364

26. Auroux A (2008) In: Karge HG, Weitkamp J (eds) Acidity and basicity, molecular sieves, vol 6 . Springer, Berlin, p 141

27. Zhao H, Bennici S, Cai J, Shen J, Auroux A (2010) J Catal 274:259-272

28. Pinto RR, Borges P, Lemos MANDA, Lemos F, Vedrine JC, Derouane EG, Ribeiro RF (2005) Appl Catal A 284:39-46

29. Hsu T, Munson EJ, Haw JF (1994) J Am Chem Soc 116:1962-1972

30. Adeeva V, Haan JW, Jachen J, Lei GD, Schunemann V, Ven LJM, Sachtler WMH, van Santen RA (1995) J Catal 151:364-372

31. Zheng A, Zhang H, Lu X, Liu SB, Deng F (2008) J Phys Chem B 112:4496-4505

32. Fang H, Zheng A, Chu Y, Deng T (2010) J Phys Chem C 114:12711-12718

33. Xu T, Kob N, Drago RS, Nicholas JB, Haw JF (1997) J Am Chem Soc 119:12231-12239

34. Mayer U, Gutmann V, Gerger W (1975) Monats Chem 106:1245-1257

35. Simone A, Spange A, Zimmermann Y (2000) J Phys Chem B 104:6429-6438

36. Matsuhasi H, Arata K (2004) Phys Chem Chem Phys 6:2529-2533

37. Katada N, Tsubaki T, Niwa M (2008) Appl Catal A 340:76-86

38. Yu H, Fang H, Zhang H, Li B, Deng F (2009) Catal Commun 10:920-924

39. Bunnett JF, Olsen FP (1966) Can J Chem 44:1917-1931

40. Venkatesh KR, Hu J, Dogan C, Tierney JW, Wender I (1995) Energy Fuels 9:888-893

41. Marczewski M, Jakubiak A, Marczewska H, Frydrych A, Gontarz A, Śnieguła A (2004) Phys Chem Chem Phys 6:2513-2522

42. Marczewski M, Kamińska E, Marczewska H, Godek M, Rokicki G, Sokołowski J (2013) Appl Catal B 129:236-246

43. Marczewski M, Kamińska E, Marczewska H (2013) Reac Kinet Mech Cat 108:59-68

44. Marczewski M, Kamińska E, Marczewska H, Ciecierska K, Walczyk W (2014) Reac Kinet Mech Cat 11:549-567

45. Guisnet M (1990) Acc Chem Res 23:392-398

46. Guzman-Castillo ML, Lopez-Salinas E, Fripiat JJ, Sanchez-Valente J, Hernandez-Beltran F, Rodriguez-Hernandez A, Navarrete-Bolanos J (2003) J Catal 220:317-325

47. Kazansky VB (2002) Catal Today 73:127-137

48. Pines H (1981) The chemistry of hydrocarbon conversions. Academic. Press, New York, pp 27, 39, 43,44

49. Wristers J (1975) J Am Chem Soc 97:4312-4316

50. Johnson DC, Katritzky AR, Shapiro SA (1969) J Am Chem Soc 91:6654-6662

51. Gillespie RJ, Peel TE, Robinson EA (1971) J Am Chem Soc 93:5083-5087

52. Olah GA, Batamack P, Deffieux D, Török B, Wang Q, Prakash GKS (1996) Appl Catal 146:107-117

53. Greenberg A, Liebman JF (1982) J Org Chem 47:2084-2088

54. Kolboe S (2011) J Phys Chem A 111:3106-3115

55. Benitez VM, Yori JC, Vera CR, Pieck CL, Grau JM, Parera JM (2005) Ind Eng Chem Res 44:1716-1721

56. Goncalves VLC, Rodrigues RC, Lorencato R, Mota CJA (2007) J Catal 248:158-164

57. Yang T, Chang T, Yeh Ch (1997) J Mol Catal A 115:339-346

58. Gawthrope DE, Lea AF, Wilson K (2004) Phys Chem Chem Phys 6:3907-3914

59. dos Santos ACB, Kover WB, Faro AC (1997) Appl Catal A 153:83-101 